\section{BRAZIULIAN JOURNAL}

OF MEDICAL AND BIOLOGICAL RESFARCH

www.bjournal.com.br
ISSN 0100-879X

Volume 43 (9) 812-913 September 2010

BIOMEDICAL SCIENCES

AND

CLINICAL INVESTIGATION

Braz J Med Biol Res, September 2010, Volume 43(9) 816-820

doi: 10.1590/S0100-879X2010007500074

Mitochondrial control region haplotypes of the South American sea lion Otaria flavescens (Shaw, 1800)

L.O. Artico, A. Bianchini, K.S. Grubel, D.S. Monteiro, S.C. Estima, L.R. de Oliveira, S.L. Bonatto and L.F. Marins

The Brazilian Journal of Medical and Biological Research is partially financed by
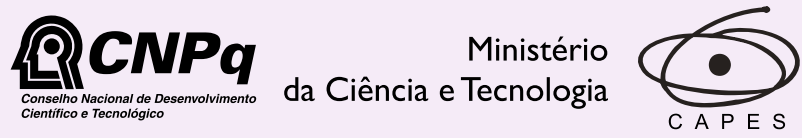

Ministério da Educação

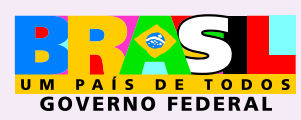

DFAPESP

Institutional Sponsors
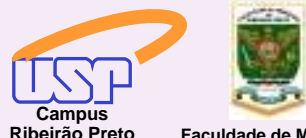

Ф SHIMADZU

GE Healthcare
Hotsite of proteomics metabolomics developped by:

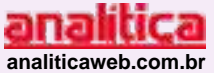

Thermo
SCIEN TIFIC 


\title{
Mitochondrial control region haplotypes of the South American sea lion Otaria flavescens (Shaw, 1800)
}

\author{
L.O. Artico ${ }^{1}$, A. Bianchini ${ }^{1}$, K.S. Grubel ${ }^{2}$, D.S. Monteiro², S.C. Estima ${ }^{2}$, \\ L.R. de Oliveira ${ }^{3}$, S.L. Bonatto ${ }^{4}$ and L.F. Marins ${ }^{1}$ \\ ${ }^{1}$ Instituto de Ciências Biológicas, Universidade Federal do Rio Grande, Rio Grande, RS, Brasil \\ ${ }^{2}$ Núcleo de Educação e Monitoramento Ambiental, Rio Grande, RS, Brasil \\ ${ }^{3}$ Laboratório de Ecologia de Mamíferos, Programa de Pós-Graduação em Biologia, \\ Diversidade e Manejo de Vida Silvestre, Universidade do Vale do Rio dos Sinos, São Leopoldo, RS, Brasil \\ ${ }^{4}$ Centro de Biologia Genômica e Molecular, Pontifícia Universidade Católica do Rio Grande do Sul, \\ Porto Alegre, RS, Brasil
}

\begin{abstract}
The South American sea lion, Otaria flavescens, is widely distributed along the Pacific and Atlantic coasts of South America. However, along the Brazilian coast, there are only two nonbreeding sites for the species (Refúgio de Vida Silvestre da Ilha dos Lobos and Refúgio de Vida Silvestre do Molhe Leste da Barra do Rio Grande), both in Southern Brazil. In this region, the species is continuously under the effect of anthropic activities, mainly those related to environmental contamination with organic and inorganic chemicals and fishery interactions. This paper reports, for the first time, the genetic diversity of $O$. flavescens found along the Southern Brazilian coast. A 287-bp fragment of the mitochondrial DNA control region (D-loop) was analyzed. Seven novel haplotypes were found in 56 individuals (OFA1-OFA7), with OFA1 being the most frequent (47.54\%). Nucleotide diversity was moderate $(\pi=0.62 \%)$ and haplotype diversity was relatively low $(67 \%)$. Furthermore, the median joining network analysis indicated that Brazilian haplotypes formed a reciprocal monophyletic clade when compared to the haplotypes from the Peruvian population on the Pacific coast. These two populations do not share haplotypes and may have become isolated some time back. Further genetic studies covering the entire species distribution are necessary to better understand the biological implications of the results reported here for the management and conservation of South American sea lions.
\end{abstract}

Key words: Otaria flavescens; mtDNA; D-loop; Genetic variability; New haplotypes

\section{Introduction}

The South American sea lion, Otaria flavescens (Shaw, $1800)$, is widely distributed along the coasts of South America, occurring from $6^{\circ} \mathrm{S}$ in the Pacific Ocean to $29^{\circ} \mathrm{S}$ in the Atlantic Ocean. The main breeding colonies are located in Uruguay, Argentina, Falkland Islands (UK), Chile, and Peru (1). This is not a migratory species, although seasonal movements occur when adult males, after the breeding season, move to the sea searching for food (2). The South American sea lion is one of the most frequent pinniped species in Brazil, occurring mainly during winter and spring. According to Rosas et al. (3), specimens found along the Southern Brazilian coast are part of the breeding stock of Uruguayan rookeries. However, some specimens from the Argentinian stock were also recorded in Cambo- riú Beach (Santa Catarina, Southern Brazil) (Barreto AS, personal communication).

There are only two nonbreeding sites for the species along the Brazilian coast: Refúgio de Vida Silvestre da Ilha dos Lobos $\left(29^{\circ} 20^{\prime} \mathrm{S}, 49^{\circ} 43^{\prime} \mathrm{W}\right)$ at Torres and Refúgio de Vida Silvestre do Molhe Leste da Barra do Rio Grande $\left(32^{\circ}\right.$ $10^{\prime} \mathrm{S}, 52^{\circ} 6^{\prime} \mathrm{W}$ ) in the Lagoa dos Patos, both on the coast of the Rio Grande do Sul (2). Rosas et al. (2) observed that most animals present on the Rio Grande do Sul coast were males (81\%), represented mainly by large numbers of immature individuals from April to June. In a previous study investigating aging by the same authors (3), skulls and teeth of $O$. flavescens found dead along the southern coast of Brazil were collected. The oldest males and females

Correspondence: L.F. Marins, Universidade Federal do Rio Grande/FURG, Av. Itália, km 8, 96201-900 Rio Grande, RS, Brasil.

Fax: +55-53-3233-6851/3233-6848. E-mail: dqmluf@furg.br

Received March 22, 2010. Accepted July 20, 2010. Available online July 30, 2010. Published September 13, 2010. 
were 16 and 14 years old, respectively. Animals aged 3-5 years were the most frequent. Both sexes attain $95 \%$ of their maximum length by 8 years of age (3). Kinas et al. (4) suggest a strong seasonal pattern for $O$. flavescens with a maximum average number of strandings in September and a minimum in January. The estimated stranded sea lion in a typical year is 115 sea lions.

There are only few studies published about South American sea lions on the Brazilian coast. Most of them are related to seasonal movements (2), age and growth (3), patterns of occurrence (4), diet and fishery interactions (5) on the Southern Brazilian coast. However, there is no information about the genetic diversity of the species in Brazil. The only published studies on the genetics of pinnipeds from the Southern Brazilian coast are those by Ferreira et al. (6) and Oliveira et al. (7) regarding Arctocephalus tropicalis and Arctocephalus australis, respectively. Therefore, we present here, for the first time, an evaluation of the genetic diversity of $O$. flavescens found on the Southern Brazilian coast and compare the results obtained with existing data for a single population from the Southern Pacific (8).

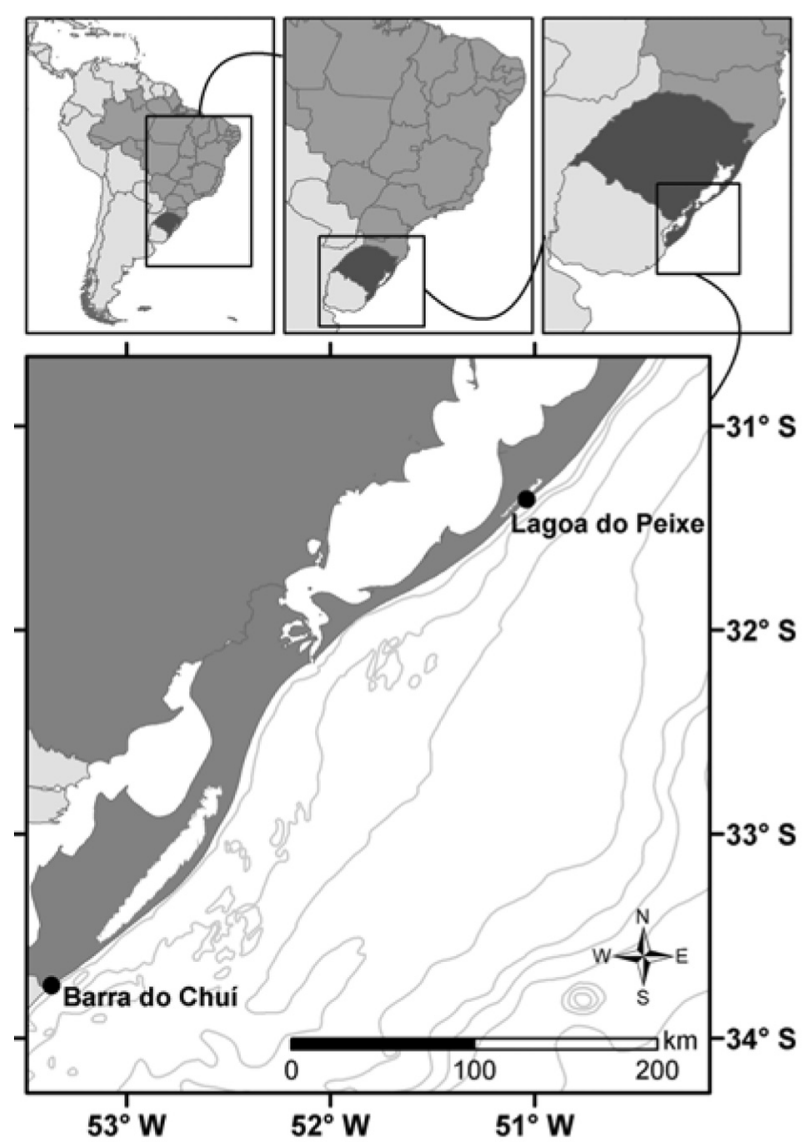

Figure 1. Sampling area of the present study. South American sea lions were collected between May 2005 and September 2006.

\section{Material and Methods}

Tissue samples (skin) were collected from 52 dead sea lions along the Rio Grande do Sul coastline between May 2005 and September 2006. Additional samples from 4 individuals were supplied by a non-governmental Brazilian organization (NEMA/Núcleo de Educação e Monitoramento Ambiental, Rio Grande, RS, Brazil). The samples were collected during beach surveys performed from June 2002 to June 2004. The area studied extends from the "Barra da Lagoa do Peixe" at Mostardas $\left(31^{\circ}\right.$ $21^{\prime} 31.9^{\prime \prime S} / 51^{\circ} 02$ ' 19.6"W) to "Barra do Chuí" (33 44' $37.7^{\prime \prime S} / 53^{\circ} 22^{\prime} 10.5^{\prime \prime} \mathrm{W}$; Figure 1). For each specimen sampled, the following data were recorded: date, season, body length (from the tip of the snout to the end of the tail), geographic coordinates, sex (based on external morphology), and degree of decomposition. Tissue samples of approximately $1 \mathrm{~cm}^{3}$ were collected and preserved in 95\% ethanol. Total genomic DNA was extracted using the standard phenol-chloroform and ethanol precipitation protocol by the method of Sambrook et al. (9). A 287-bp fragment from the mitochondrial DNA control region was amplified by polymerase chain reaction (PCR) using a TC512 automatic thermal cycler (Techne, UK) with a $25-\mu \mathrm{L}$ reaction volume: $1 \mu \mathrm{L}$ genomic DNA(10 ng DNA template), 19.05 $\mu \mathrm{L}$ MilliQ ${ }^{\circledR}$ water, $0.75 \mu \mathrm{L}(10 \mathrm{mM}) \mathrm{dNTP}$ mixture, $0.6 \mu \mathrm{L}(50 \mathrm{mM}) \mathrm{MgCl}_{2}, 2.5 \mu \mathrm{L}$ (10X) buffer $(500 \mathrm{mM} \mathrm{KCl}$, $200 \mathrm{mM}$ Tris- $\mathrm{HCl}, \mathrm{pH} 8.4), 0.5 \mu \mathrm{L}(10 \mathrm{pmol} / \mu \mathrm{L})$ of universal primers [DL-FOR (5'-TTCCCCGGTCTTGTAAACC-3') and DL-REV (5'-ATTTTCAGTGTCTTGCTTT-3')] (10) and $0.2 \mu \mathrm{L}$ Taq DNA Polymerase (Invitrogen, Brazil; $5 \mathrm{U} / \mu \mathrm{L}$ ). PCR conditions were a denaturation step at $94^{\circ} \mathrm{C}$ for 1 min, followed by 30 cycles (denaturation at $94^{\circ} \mathrm{C}$ for 30 $\mathrm{s}$, annealing at $50^{\circ} \mathrm{C}$ for $1 \mathrm{~min}$ and extension at $72^{\circ} \mathrm{C}$ for $1 \mathrm{~min}$ ) and $5 \mathrm{~min}$ at $72^{\circ} \mathrm{C}$ for final extension. Products were characterized by electrophoresis on $1 \%$ agarose gel (Invitrogen, Brazil) stained with ethidium bromide prepared in Tris-acetate EDTA. PCR products were then purified with PEG 8000 (Promega, USA) and sequencing was performed using a MegaBace 1000 automatic sequencer (GE Healthcare, Brazil).

Sequence electropherograms were checked with the Chromas software (Technelysium, Australia). The sequences obtained were aligned using Clustal X (11), manually edited with Bioedit 6.0.7 (Sequence Alignment Editor $\left.^{(}\right)$, and corrected visually.

Genetic variability was estimated using haplotype (h) and nucleotide $(\pi)$ diversities, which were calculated with the DnaSP 4.0 software (12). A median joining network method was generated to infer the relationships between the novel haplotypes from the Atlantic population and the Peruvian population on the Pacific coast (8) obtained from GenBank (accession Nos. AF384419, AF384420, AF384421, AF384422, AF384423) using Network 4.5 (13) (Figure 2). 


\section{Results}

A total of 56 sequences of the mtDNA control region were obtained for analysis, which comprised $287 \mathrm{bp}$. These sequences defined seven new and different haplotypes for the species analyzed, represented by white circles in Figure 2. The most common and widespread haplotype, OFA1, was shared by 29 individuals representing $47.54 \%$ of the sample, followed by the haplotypes OFA2 (18.3\%; $\mathrm{N}=11)$, OFA3 (16.39\%; $\mathrm{N}=10)$, OFA4 and OFA5 (3.27\%; $\mathrm{N}=2$ ), and OFA6 and OFA7 (1.63\%; $N=1)$. These seven haplotypes (OFA1-7) were considered to be new since they are different from the previous haplotypes described for the species by Wynen et al. (8). All unique haplotypes were submitted to GenBank (accession Nos. EU044835EU044841).

Results obtained by the median-joining network method using D-loop sequences for the haplotypes described in this study and representative haplotypes from the Pacific Ocean, represented by gray circles, are shown in Figure 2. These analyses demonstrate the reciprocal monophyly of O. flavescens, with a grouping of haplotypes OFA1-OFA7 being from the Atlantic Ocean population, and specimens from Peru being from the Pacific Ocean group (haplotypes OB4, OB5 and OB2) (8).

Moderate levels of genetic diversity were observed among $O$. flavescens individuals. The haplotype $(\mathrm{h})$ and nucleotide $(\pi)$ diversities calculated for the species were $0.67 \pm 0.051$ and $0.006 \pm 0.00067$, respectively.

\section{Discussion}

The nucleotide diversity observed $(0.006 \pm 0.00067)$ is consistent with values reported by Wynen et al. (8) for the same region of mtDNA of other sea lion species and populations, such as $O$. flavescens from the Pacific coast $(\pi=0.008)$, Eumetopias jubatus from Alaska $(\pi=0.004)$, and Phocarctus hookeri from New Zealand $(\pi=0.004)$. However, other investigators found that Zalophus californianus from the California coast and Callorhinus ursinus from Alaska had significantly higher levels of nucleotide diversity ( $\pi=0.03$ and 0.027 , respectively). Therefore, the result observed for $O$. flavescens in the present study is within the range of nucleotide diversity described for other sea lion species. Regarding haplotype diversity, a relatively low value was observed $(h=67 \%)$ for $O$. flavescens when compared to other pinnipeds. High levels of haplotype diversity ( $\mathrm{h}=93 \%$ ) were reported for $E$. jubatus sampled in Alaska after analysis of $531 \mathrm{bp}$ of the mtDNA control region (14). Also, 91\% haplotype diversity was reported for E. jubatus individuals sampled in the North Pacific and Bering Sea, after analysis of $238 \mathrm{bp}$ of the mtDNA control region (15). For Phoca vitulina from the North Pacific, a haplotype diversity of $97 \%$ was observed after analysis of $435 \mathrm{bp}$ of the mtDNA control region (16). In fur

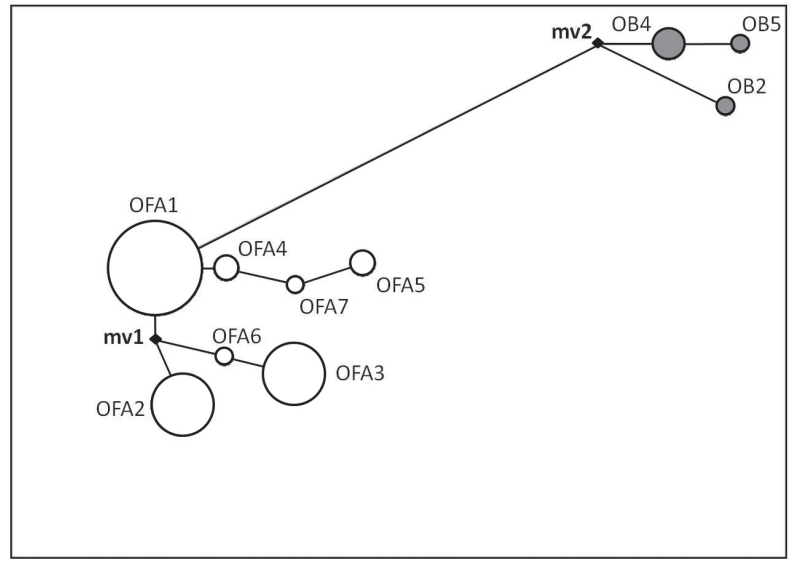

Figure 2. Median-joining network of the Atlantic (white circles) and Peruvian (gray circles) haplotypes based on polymorphic sites of the mitochondrial D-loop region. The circled areas are proportional to the frequency of the haplotypes indicated. Black diamonds symbolize median vectors $(\mathrm{mv})$ produced by the network software, representing missing or not sampled haplotypes.

seal samples (Arctocephalus philippii) from Chile, a high haplotype diversity $(\mathrm{h}=90 \%$ ) was reported after analysis of $315 \mathrm{bp}$ of the mtDNA control region (17). A very similar value $(\mathrm{h}=91.4 \%$ ) was observed for the harbor porpoise, Phocoena phocoena, sampled in the Northwest Atlantic, when analyzing the same mtDNA region (18).

The moderate haplotype diversity observed in sea lions from Southern Brazil could be explained by the single Uruguayan origin of the individuals analyzed. This hypothesis is consistent with the reduced genetic variability of cytochrome $b$ described for $O$. flavescens sea lions and $A$. australis fur seals from Uruguay and Argentina, associated with the recent colonization of these areas (19).

The molecular data reported in the present study are the first genetic information for South American sea lions from the Brazilian coast. The evidence of reciprocal monophyletic clades and the absence of shared haplotypes between Brazilian and Peruvian specimens indicated that these populations may have become isolated some time back. Median joining network analysis performed with D-loop region haplotypes (Figure 2) showed a subdivision of the O. flavescens population into two main clades: the Peruvian and the Brazilian groups of haplotypes. These two clades may reflect a possible differentiation between Atlantic and Pacific sea lions at some taxonomic level, as proposed by Túnez et al. (19). This separation can be characterized by the representation of the median vector (mv2), possibly an ancestral haplotype, among clades in the Pacific and Atlantic populations, which, after several changes over time, led to the Atlantic clade (Figure 2). The median vector mv1 may represent a not scored or ancestral haplotype, which gave origin to a group formed by OF6, OF3 and OF2. 
Glacial episodes usually induced important evolutionary events in populations, considering that they constitute physical barriers for dispersion and genetic flow (20). Glaciations associated with geographic distances may have been the cause of a significant reduction in gene flow between Pacific and Atlantic colonies of the Southern sea lions, as suggested by the lack of shared haplotypes observed between these populations, as described by Túnez et al. (19) for the cytochrome $b$ gene, and corroborated by our results for the mtDNA D-loop region.

The two populations compared in the present study are the most distant ones geographically, thus explaining the genetic difference observed between them. However, for any future comment or suggestion on the systematic, conservation and/or management plan for the studied species we strongly recommend further studies considering additional new samples to cover the entire species distribution. This should include individuals from Argentina, Falkland Islands and Chile. This action would take into account the most important breeding colonies of the species as well as the potential connection points between populations in the Southern tip of South America. In addition, we also suggest new analyses using other molecular markers such as microsatellites as well as morphological

\section{References}

1. Vaz-Ferreira R. South American sea lion, Otaria flavescens (Shaw, 1800). In: Ridgway SH, Harrison R (Editors), Handbook of marine mammals. London: Academic Press; 1981. p 39-65.

2. Rosas FCW, Pinedo MC, Marmontel M, Haimovici M. Seasonal movements of the South American sea lion (Otaria flavescens, Shaw) off the Rio Grande do Sul coast, Brazil. Mammalia 1994; 58: 51-59.

3. Rosas FCW, Haimovici M, Pinedo MC. Age and growth of the South American sea lion, Otaria flavescens (shaw, 1800), in Southern Brazil. J Mammal 1993; 74: 141-147.

4. Kinas PG, Silva KG, Estima SC, Monteiro DS. Generalized linear models applied to stranding data of South American sea lions (Otaria flavescens) and South American fur seals (Arctocephalus australis) in Southern Brazil. Lat Am J Aquat Mamm 2005; 4: 7-14.

5. Oliveira LR, Ott PH, Malabarba LR. Ecologia alimentar dos pinípedes do Sul do Brasil e uma avaliação de suas interações com atividades pesqueiras. In: Reis NRd, Peracchi AL, Dos Santos GASD (Editors), Ecologia de mamíferos. Londrina: Technical Books Editora; 2008. p 97-116.

6. Ferreira JM, Oliveira LRd, Wynen L, Bester MN, Guinet C, Moraes-Barros N, et al. Multiple origins of vagrant Subantarctic fur seals: a long journey to the Brazilian coast detected by molecular markers. Polar Biol 2008; 31: 303-308.

7. Oliveira LR, Hoffman JI, Hingst-Zaher E, Majluf P, Muelbert MMC, Morgante JS, et. al. Morphological and genetic evidence fot two evolutionarily significant units (ESUs) in the South American fur seal, Arctocephalus australis. Conserv Genet 2008; 9: 1451-1466. and behavioral studies to identify evolutionarily significant units of the species (5).

Finally, it is important to note that, in spite of the anthropic impacts on O. flavescens populations along the South American coast, this species is still considered to be of least concern in the IUCN 2008 Red List of Threatened Species. In this context, we believe that the results reported in this present study may serve as a baseline for future studies involving populations of South American sea lions and future actions for their conservation and management.

\section{Acknowledgments}

We thank Cladinara Roberts Sarturi and Raquel dos Santos Almeida (Laboratório de Biologia Genômica e Molecular, Pontifícia Universidade Católica do Rio Grande do Sul; PUCRS, Brazil) for helping with the DNA sequencing procedures. We are also grateful to NEMA for supplying the biological samples. Maira Proietti and Tiago Gandra are also acknowledged for reviewing the manuscript and for map construction (Geographical Information Systems). Research partially supported by the "Fundação O Boticário de Proteção à Natureza" (Brazil). L.O. Artico, A. Bianchini, and S.L. Bonatto are Research Fellows of CNPq.

8. Wynen LP, Goldsworthy SD, Insley SJ, Adams M, Bickham $\mathrm{JW}$, Francis J, et al. Phylogenetic relationships within the eared seals (Otariidae: Carnivora): implications for the historical biogeography of the family. Mol Phylogenet Evol 2001; 21: 270-284.

9. Sambrook j, Fritsch EF, Maniatis T. Molecular cloning: $A$ laboratory manual. New York: Cold Spring Harbor Laboratory Press; 1989.

10. Hoelzel AR. Molecular genetic analysis of populations. New York: Oxford University Press; 1994.

11. Thompson JD, Gibson TJ, Plewniak F, Jeanmougin F, Higgins DG. The CLUSTAL_X windows interface: flexible strategies for multiple sequence alignment aided by quality analysis tools. Nucleic Acids Res 1997; 25: 4876-4882.

12. Rozas J, Sanchez-DelBarrio JC, Messeguer X, Rozas R. DnaSP, DNA polymorphism analyses by the coalescent and other methods. Bioinformatics 2003; 19: 2496-2497.

13. Bandelt HJ, Forster P, Rohl A. Median-joining networks for inferring intraspecific phylogenies. Mol Biol Evol 1999; 16: $37-48$.

14. O'Corry-Crowe G, Taylor BL, Gelatt T, Loughlin TR, Bickham J, Basterretche M, et al. Demographic independence along ecosystem boundaries in Steller sea lions revealed by mtDNA analysis: implications for management of an endangered species. Can J Zool 2006; 84: 1796-1809.

15. Baker AR, Loughlin TR, Burkanov V, Matson CW, Trujillo RG, Calkins DG, et al. Variation of mitochondrial control sequences of Steller sea lions: the three-stock hypothesis. J Mammal 2005; 86: 1075-1084.

16. Westlake RL, Corry-Crowe GM. Macrogeographic structure 
and patterns of genetic diversity in harbor seals (Phoca vitulina) from Alaska to Japan. J Mammal 2002; 83: 11111126.

17. Goldsworthy S, Francis J, Boness D, Fleischer R. Variation in the mitochondrial control region in the Juan Fernandez fur seal (Arctocephalus philippii). J Hered 2000; 91: 371-377.

18. Rosel PE, France SC, Wang JY, Kocher TD. Genetic structure of harbour porpoise Phocoena phocoena populations in the northwest Atlantic based on mitochondrial and nuclear markers. Mol Ecol 1999; 8: S41-S54.

19. Túnez Jl, Centrón D, Cappozzo HL, Cassini MH. Geographic distribution and diversity of mitochondrial DNA haplotypes in South American sea lions (Otaria flavescens) and fur seals (Arctocephalus australis). Mamm Biol 2007; 72: 193-203.

20. Godfrey MH. Some genetic consequences of ice ages, and their role, in divergence and speciation. Biol J Linn Soc Lond 1996; 58: 247-276. 